\title{
Chiles: A Gift from a Fiery God
}

\author{
Paul W. Bosland \\ Agronomy and Horticulture Department, New Mexico State University, Las Cruces, NM 88003-0003
}

Our horticultural heritage with chiles (Capsicum sp.) begins 10,000 to 12,000 years ago, when our ancestors first began to inhabit the Western Hemisphere. The brave ancestor that took the first taste of chile fruit was rewarded for this adventuresomeness in gastronomy with a sharp pain. The amazing part is that our ancestors did not avoid this plant of pain but worshipped it as a gift from the gods. Furthermore, the domestication of chile was not an isolated event. Because of the existence of five different domesticated species, we can infer that chiles were probably domesticated at least five different times. What were the mystical and spiritual powers that our ancestors believed chiles possessed?

\section{HISTORICAL}

Chile was one of the first plants to be domesticated and cultivated in the Western Hemisphere. Chile seeds and chile fragments in coprolites dating back 9000 years have been found in excavations in Tamaulipas and Tehuacán, Mexico (MacNeish, 1964), and a handful of C. baccatum L. seeds found in a South American cave was estimated to be 7000 years old. Because the seeds are similar in size to the seeds of the domesticated baccatums of Peru, it is theorized that chile is one of the oldest domesticated crops (Pickersgill, 1969).

Archaeologists and historians have not placed much emphasis on chiles in their discussions. Chiles are considered a marginal part of preColumbian agriculture, not as a source of protein or carbohydrates to sustain a civilization. Instead, they are viewed as a minor crop used only for seasoning. Even though the cultivated area of chiles was (and still is) small, they played an important part in the daily lives of the Americans. Remember also that spices, with their incredible value, inspired Columbus to voyage westward in search of a new route to India.

Received for publication 16 July 1998. Accepted for publication 1 Dec. 1998. A contribution of the New Mexico Agricultural Experiment Station, New Mexico State Univ., Las Cruces. The cost of publishing this paper was defrayed in part by the payment of page charges. Under postal regulations, this paper therefore must be hereby marked advertisement solely to indicate this fact.
Gary Nabhan (1995), in his book Gathering the Desert, describes a portion of the creation myth from the Cora Indians of Mexico's west coast as written by a Franciscan priest in 1673 .

The Maker created a man and a woman. The man was called Narama, the woman Uxuu. He put them in a place with many fruits and minerals, but afterwards cast them out. Then Narama began to sweat, and his sweat was changed into salt. The Maker chose him the patron saint of salt, mescal, and chile. Other creatures peopling the earth were assigned to be the nurturers of additional foods, vegetables, or animals.

A few days after having made these arrangements, the Maker invited all these people to a fantastic fiesta. He set a table in the middle of the earth, and each creature brought the foods entrusted to them, to share. Narama was among the last, and he came naked, covered with salt. After everyone was already seated, he presented himself at the table, took salt from his face and sprinkled it upon the food. Then he reached down, and his testes turned into chile pods. He began to sprinkle this spice onto all of the foods.

This crude action annoyed all the other patrons, who angrily scolded Narama. To this he replied that if the others could provide the fruits, fish, fowl, seeds, and vegetables that were the basic staples of the fiesta, why could not he provide something that these foods needed to be truly tasteful? He declared that there was nothing so necessary as salt and chile. If they would just try the food both with and without these ingredients, they would know that in their heart. They ate, and not only became satisfied, but enthusiastic.

In 1609, Garcilaso de la Vega in his Royal Commentaries of the Incas wrote that Incas worshiped chile as one of the four brothers of their creation myth, and as the brother of the first Inca king. The chile pods were perceived to symbolize the teachings of the early ancestors. Within their society, chiles were holy plants and had to be avoided when fasting. Incas decorated pottery and clothing with chiles. An obelisk from the Chavín culture in Peru has a carving of the black 
caiman, a mythical creature, and in its claws are the pods of chiles. This suggests that Incas believed there were inherent spiritual powers in the chiles.

In the Aztec and Mayan cultures, chiles were also held in high regard and were withheld from their diets when fasting to earn favors and to please the gods. Today, sorcerers and shamans of the native peoples prescribe chiles, not so much to cure a current affliction, but to prevent future maladies caused by lack of harmony with one's surroundings or for protection against future evil witchcraft.

Chile was one of the most common tribute items in pre-Columbian times and continued to be so after the Spanish conquest. Tribute was a form of taxation by the Incas and Aztecs, and was adopted by the Spanish after their arrival in Mexico. Chile tributes to dignitaries were common. In 1550, Don Juan de Guzmán, the governor of Coyoacan in the Valley of Mexico, received 700 chiles per week as tribute. In Peru, the Inca ruler Huayna Capac ordered the nobles of Cuzco to purchase coca and chiles so that he could perform the fiesta of Purucaya as a tribute to his mother. The Purucaya was a very special fiesta in Inca life and was performed to show great respect to the deceased. The ceremony would be comparable to canonizing someone today.

The use of chile by the native Americans in the southwestern United States is not as clearly demonstrated. Chiles are deeply rooted in the customs of the Papago Indians, an Arizona tribe directly descended from the ancient, extinct Hohokam peoples. This indicates that chiles were in use before the Spanish conquest. We do not know if chiles were cultivated by the Pueblo Indians of the southwest. The historian for Coronado reported that the native peoples sprinkled chile on dry meat. The Pueblo Indians could have grown chiles, but only as an annual crop because of killing frosts during the winter (DeWitt and Bosland, 1993). More likely, the Pueblo Indians acquired them through trading with tribes in the tropical parts of Mexico. From archeological evidence, we know that the Hohokam and Anasazi traded turquoise and salt for copper bells, seashells, parrots, and possibly chiles with people in the warmer parts of Mexico. Hence, even if the Pueblo peoples did not grow chiles, they probably used them.

Columbus introduced chile to Europe, and almost immediately it was incorporated into regional cuisines. Eating habits of humans are very conservative and not adventuresome when it comes to foods. Yet in Europe, Africa, and Asia, chile was integrated into the culture without hesitation. Consumers may have assumed that the chile plant was a form of black pepper, Piper nigrum L. Thus, it was not an "unknown" food but a known food that until its introduction was only affordable by the nobility. Now peasants could grow "pepper" and flavor their dishes just as did the wealthy.

When Columbus returned to Europe with chile seed, the extensive trading routes of the Spanish and Portuguese helped spread chiles around the globe. Chiles became the famous Hungarian paprika, which aided Szent-Györgyi in his discovery of ascorbic acid, vitamin $\mathrm{C}$, for which he won the Nobel prize. In Africa, wild birds spread the chile's seed farther inland, where it became a subspontaneous crop. Chiles provide birds with vitamins, and because birds do not taste or sense the pungency, they eat them readily. In west Africa, the native peoples concocted a potion from chiles that ensured eternal youth. Dr. Livingstone told Stanley that the native women would sometimes bathe in water to which chile powder had been added in order to be more attractive. In India and China, chiles began to dominate the cuisine and became the principal spice of the region. Chile quickly became so ingrained in the foods of the region that taxonomists in the 1700 s mistook China for the origin of one of the species.

\section{UTILIZATION}

Chiles have been used as money, spice, vegetable, and medicines, and to invoke spiritual sensations. In addition to their use as tributes during the Inca empire, chiles were used as daily currency and even today purchases can be made in Peru with a handful of chiles.

The importance of chile as a seasoning in pre-Columbian times is confirmed by the writings of the Spanish chroniclers of the 16th century. Fray Bernardino de Sahagún (1569) wrote of Aztec food that in the market there were "hot green chiles, smoked chiles, water chiles, tree chiles, flea chiles, and sharp-pointed red peppers." Sahagún described in detail the pungency and aromas of these chiles. The Aztecs classified chiles into six categories based not only on level of pungency (high to low), but also on the type of pungency (sharp to broad). Thus, chile was more than a simple spice; unlike black pepper, which adds only bite, chile accentuates the flavor of the food. To further illustrate the importance of the flavor differences among the different chile types, Sahagún described how each chile was used in dishes. He wrote "frog with green chile, newt with yellow chile, tadpoles with small chiles," and so on.

Most reference books list the fruit of the chile plant as the edible part. In the fresh state, it is an important vegetable in many cultures. An overlooked use of chiles is their use as a green, leafy vegetable. In the Philippines, chile leaves are added to soups and stews. Asian markets in the United States often carry frozen chile leaves. Real aficionados prefer fresh, young, tender leaves harvested before the plant begins to produce flowers. In the markets of the Philippines, the upper shoots of the plants are sold in bunches much like spinach is in the United States. Filipinos say they can taste the difference between leaves from $C$. annuum L. and C. frutescens L. Unlike the leaves of chile's close relatives, tomato and potato, chile leaves lack the alkaloid compounds that make solanaceous foliage unpalatable and even dangerous to consume. Childers and Russo (1977) recommended that arthritis sufferers avoid eating dishes made from the nightshade family. This belief is based on the idea that the common nightshade alkaloid, solanine, is responsible for the aches and pains of most cases of arthritis. Actually, chile pungency as a counterirritant is one of the best remedies for the pain of arthritis. Thus, although chile may be a member of the deadly nightshade family, it is not poisonous. However, some who consume a very hot chile may think that they are dying at the time!

Given the availability of other fruits and vegetables high in nutritional value, why did our ancestors domesticate and grow chiles? It may have been the myriad fruit shapes and colors of chiles that interested them (DeWitt and Bosland, 1996), or the flavor and aroma that are as important in chiles as are color and form. The most potent volatile in chiles is 2-methoxy-3-isobutyl-pyrazine, the "bell pepper" smell. Humans can detect this volatile at concentrations lower than any other compound known. However, in spite of these attributes, it was probably pungency that caused our ancestors to invest considerable time and energy into growing and improving chiles.

The popularity and spiritual essence of chiles is associated with pungency. Some have argued that pungency should be one of the five main tastes, along with bitter, sweet, sour, and salty. Pungency is produced by the capsaicinoids, alkaloid compounds that are unique to the genus Capsicum. Chile pungency, or the sensation of heat, is expressed in Scoville Heat Units (SHU). Originally, this was measured organoleptically, but now is measured by high-performance liquid chromatography. The capsaicinoids are produced in glands on the placenta of the fruit. While seeds are not the source of pungency, they occasionally absorb the capsaicinoids because of their proximity to the placenta.

\section{MEDICINAL USE}

Chile's medicinal applications have brought renewed interest to the capsaicinoids. Chiles were used for more than just a food or spice in pre-Columbian times because of their unique pungency. Chile was probably first used as a medicinal plant; Mayans used chiles to treat asthma, coughs, and sore throats. In Columbia, the Tukano group use chiles to relieve a hangover. After a night of dancing and drinking alcoholic beverages, the Tukanos pour a mixture of crushed chile and water into their noses to relieve the effects of the festivities. The Aztecs and the Mayas mixed chile with maize flour to produce chillatolli, a cure for the common cold. The Aztecs placed a drop or two of chile juice on a tooth to stop pain. In 1590, while living in Mexico, the priest Acosta remarked that "when the chile is taken moderately it helps and comforts the stomach for digestion, but if they take too much it has bad effects." He also stated that chile was bad for the "health of young folks, chiefly their souls, because consuming chile provokes lust."

Capsaicin has been prescribed for severe chronic pain conditions, where it is usually administered topically for periods of several weeks, 
as in the case of Herpes zoster or "shingles." It is also effective against cluster headaches. The beneficial effects associated with consumption of chiles by some ethnic groups, and its effects on the gastrointestinal tract, the cardiovascular system, the sensory system, thermoregulation, and nutrition, have been well documented (Campbell and Baker, 1990; Carmichael, 1991).

Chile pungency is not the only medicinal use for chiles. A home remedy for relieving pain and swelling is to make a poultice out of chile leaves and vegetable oil and place it on the afflicted area. In addition, chiles have high concentrations of vitamins $\mathrm{A}, \mathrm{C}$, and $\mathrm{E}$, the antioxidative vitamins (Osuna-Garcia, et al., 1998).

Chile was used not only as a reward or to cure sickness, but also as punishment. In the Mendocino Codex (a codex was a method of recording information, usually in the form of paintings) the daily life of Aztecs was described, including a common form of punishment for children. The Codex has a drawing of a father punishing his 11-yearold son by making the boy inhale smoke emanating from dry chiles roasting on the hearth. In the same drawing, a mother threatens her 6year-old daughter with the same punishment. Today, we have "pepper spray," which is standard issue for many police departments in the United States to control unruly criminals.

\section{POD-TYPE DIVERSITY}

It took many millennia of patience and hard work to develop the innumerable pod types of chile. By the time Columbus arrived, the Aztecs had already developed several pod types, including jalapeños, pasilla, ancho, de arbol, and mirasol. Improvement in these aboriginal pod types by researchers has continued and many new cultivars are available today.

One of the most important pod types in use today, known as "Anaheim" or "New Mexican" pod type, is a modern invention developed at New Mexico State Univ. The New Mexican pod is $15 \mathrm{~cm}$ long and $3 \mathrm{~cm}$ wide at the shoulders. The pungency ranges from zero for paprika use to 7000 SHU for the "hot" cultivars. All New Mexicantype chiles grown today gained their genetic base from cultivars first developed at New Mexico State Univ.

The New Mexican pod-type selection began in 1894 when Dr. Fabian Garcia began improving the local chiles grown by Hispanic gardeners around Las Cruces, N.M. Before the development of the New Mexican pod type, there was no control over the genetic constitution of the chile seeds planted, so farmers could never predict size or heat of the pods. Dr. Garcia thought that if he made the chiles milder, consumption would increase among the Anglo population. From the two colors of chile available to him, red (colorado) or black (negro), he chose the former. This was fortuitous because 100 years later, chile's (paprika) use as a red coloring agent has become an important component of the chile industry. His improvement of native chile was by selection and crossbreeding. His goal was to produce a chile cultivar that was a "larger, smoother, fleshier, more tapering, and shoulderless pod for canning purposes." He selected 14 accessions of pasilla (dark brown), colorado, and negro chiles that were growing in the Las Cruces area.

In 1913, after 9 years of growing and selecting, Dr. Garcia released the first New Mexico State Univ. chile cultivar, 'New Mexico No. 9', which, in Dr. Garcia's words, had "proven to be the best" (Garcia, 1921). He stated that "... while No. 9 is not quite as hot or pungent as most of the unimproved varieties, it seems to be hot enough. Most of the plants produce pods having the desired characteristics, but there are always some plants in the field which tend to revert back; consequently, it is very necessary to select the seed in the field." The pungency of 'New Mexico No. 9' was probably in the range of 1000 to 1500 SHU because it was twice as hot as 'New Mexico 6'. Until this release, the New Mexican pod type did not exist.
Dr. Garcia did not realize at the time that his chile lines were crosspollinating, resulting in new variability. In retrospect, it was serendipitous that he had picked the pasilla, colorado, and negro types. They probably intercrossed and produced progeny that contained novel gene combinations, allowing him to select for the new pod type. The 'New Mexico No. 9' became the chile standard until 1950 and helped established the "Mexican Food" industry in the United States. Today, the New Mexican pod type is the basis for the green chile, the red chile, and much of the paprika production in the world.

Chiles have been a part of the American heritage for thousands of years. Only recently has the United States begun to embrace the chile as a true American heritage crop. The small-fruited wild forms of chiles, chiltepins, of Capsicum annuum still grow wild in Arizona and Texas, making it one of the rare crops that is native to the United States. The Aztec, the Maya, and the Inca were skilled horticulturists in developing and perfecting the growing of chiles, and many of the preColumbian varieties are still grown in gardens and fields today. As horticulturists we will continue to contribute to chile's distinguished history; it may be only a short time before we say "chiles are eaten by everyone every day."

\section{Literature Cited}

Acosta, J. de. 1590. Historia natural y moral de las Indias en que se tratan las cosas notables del cielo, y elementos metales, plantas, y animales dellas: $\mathrm{Y}$ los ritos, y ceremonias, leyes, y gobierno, y guerras de los Indios. (The natural and moral history of the Indies). C.R. Markham (ed.). Lenox Hill Publ., New York. 1970. (English translation.)

Andrews, J. 1984. Peppers: The domesticated capsicums. Univ. of Texas Press, Austin.

Betanzos, J. de. 1576. (Suma y narración de los incas.) Narrative of the Incas by Juan de Betazos; translated and edited by Roland Hamilton and Dana Buchanan from the Palma de Mallorca manuscript. 1996. Univ. of Texas Press, Austin.

Brown, A. 1995. Eat the leaves and the fruit. Chile Pepper Inst. Nwsl. 4(3):12. New Mexico State Univ., Las Cruces.

Carmichael, J.K. 1991. Treatment of herpes zoster and postherpetic neuralgia. Amer. Family Physician 44:203-210.

Campbell, R.K. and D. E. Baker. 1990. New drug update: Capsaicin. Diabetes Educator 16:313-316.

Childers, N.F. and G.M. Russo. 1977. Nightshades and health. Somerset Press, Somerville, N.J.

Coe, S.D. 1994. America's first cuisines. Univ. of Texas Press, Austin.

De la Vega, Garcilaso 1609. Royal commentaries of the Incas (in Spanish). Translated by H.V. Livermore. Univ. of Texas Press, Austin.

DeWitt, D. and P.W. Bosland. 1993. The pepper garden. Ten Speed Press, Berkeley, Calif.

DeWitt, D. and P.W. Bosland. 1996. Peppers of the world. Ten Speed Press, Berkeley, Calif.

Durán, F.D. 1588? Historia de las Indias de Nueva-España y Islas de Tierra Firme. (The history of the Indies of New Spain, translated by D. Heyden, 1964) The Civilization of the American Indian Series, vol. 210. Univ. of Oklahoma Press, Norman.

Garcia, F. 1921. Improved variety No. 9 of native chile. New Mexico State Univ. Coop. Ext. Serv. Bul. No. 124.

MacNeish, R.S. 1964. Ancient mesoamerican civilization. Science 143:531537.

Nabhan, G.P. 1995. Gathering the desert. Univ. of Arizona Press, Tucson.

Osuna-Garcia, J.A., M.M. Wall, and C.A. Waddell. 1998. Endogenous levels of tocopherols and ascorbic acid during fruit ripening of New Mexican-type chile (Capsicum annuum L.) cultivars. J. Agr. Food Chem. 46:5093-5096.

Pickersgill, B. 1969. The archaeological record of chili peppers (Capsicum spp.) and the sequence of plant domestication in Peru. Amer. Antiquity 34:54-61.

Sanhagún, B. 1569. Historia general de las cosas de la Nueva España (Florentine Codex). (The general history of the things of New Spain; Florentine codex.) Translated by A.J.O. Anderson and C.E. Dibble. School of Amer. Res. (Santa Fe) Monogr. No. 14, Santa Fe, N.M. 